\title{
KAJIAN PERUBAHAN PENGGUNAAN LAHAN BERBASIS CITRA SATELIT PENGINDERAAN JAUH RESOLUSI MENENGAH DENGAN METODE MULTI LAYER PERCEPTRONDAN MARKOV CHAIN
}

\author{
Diana Wisnu Wardani' ${ }^{1}$ Projo Danoedoro ${ }^{2}$, dan Bowo Susilo ${ }^{3}$
}

Badan Pertanahan Nasional ${ }^{1}$, FakultasGeografi, Universitas Gadjah Mada, Yogyakarta, Indonesia ${ }^{2,3}$ wisnu-1407@yahoo.com

Diterima : Februari 2015 ; Direvisi : April 2015; Dipubikasikan: Maret 2016

\begin{abstract}
ABSTRAKPerkembangan Kota Yogyakarta yang sangat pesat mempengaruhi perubahan penggunaan lahan di daerah urban fringe salah satunya adalah Kabupaten Bantul. Perubahan penggunaan lahan yang tidak terkendali akan menimbulkan masalah sosial ekonomi dan lingkungan.Penelitian mengenai kajian perubahan penggunaan lahan berbasis citra satelit penginderaan jauh resolusi menengah dengan metode Multi Layer Perceptron dan Markov Chain di sebagian Kabupaten Bantul ini bertujuan: (a)mengkaji kemampuan citra satelit penginderaan jauh resolusi menengah Landsat untuk ekstraksi informasi penggunaan lahan tahun 2002, 2009 dan 2013, (b) mengkaji perubahan penggunaan lahan secara spasial dari tahun 2002 sampai dengan tahun 2009 serta (c) menyusun pemodelan perubahan penggunaan lahan dengan metode Multi Layer Perceptron dan Markov Chain pada tahun 2013 dengan mempertimbangkan faktor-faktor yang mempengaruhi perubahan penggunaan lahan berdasar penggunaan lahan 20022009.Faktor-faktor yang mempengaruhi perubahan (variabel perubahan) penggunaan lahan meliputi aksesbilitas (kepadatan jalan, jarak terhadap jalan, jarak terhadap sungai) dan kesesuaian lahan (kemiringan lereng). Citra penginderaan jauh multitemporal dalam penelitian ini menggunakan citra Landsat 5 TM tahun 2002, Landsat 7 ETM+ tahun 2009 dan Landsat 8 OLI tahun 2013. Penelitian ini menggunakan klasifikasi multispektral dengan metode maximum likelihood. Klasifikasi multispektral menghasilkan peta penutup lahan $(2002,2009,2013)$ yang selanjutnya diturunkan menjadi peta penggunaan lahan. Hasil perubahan penggunaan lahan $2002-$ 2009 selanjutnya dikaji dan diintegrasikan dengan variabel perubahan sebagai input dalam regresi non linear dengan Multi Layer Perceptron. Besar probabilitas perubahan ditentukan dengan metode Markov Chain. Hasil penelitian menunjukkan perubahan penggunaan lahan dari lahan pertanian menjadi permukiman pada periode tahun 2002-2009 seluas 2.766,78ha. Perubahan terluas terjadi di Kecamatan Banguntapan seluas 717,97 ha (25,21\%). Perubahan kelas penggunaan lahan hutan dan kebun campuran ke permukiman seluas 804,69ha dan perubahan terluas terjadi di Kecamatan Imogiri seluas 361,02 ha (6,63\%). Pemodelan spasial dengan menggunakan kombinasi MLP dan MC menghasilkan akurasi hasil prediksi terbaik dengan overall accuracy $86,16 \%$ dan nilai kappa sebesar 0,79 (substantial agreement).
\end{abstract}

Kata kunci: Markov Chain; multi layer perceptron; perubahan penggunaan lahan; prediksi.

ABSTRACT The enormous development of YogyakartaCity contributes significant impact on land use change in urban fringe, including Bantul Regency. Whilst, an uncontrolled land use alteration will trigger to social, economy, and environmental problems. Thus, this research aims to analyze spatial land use change in some parts of Bantul Regency in time frame of 2002 to 2009. Moreover, this research attempts to create land use change model using Multi Layer Perceptron and Markov Chain in 2013 by considering some factors that affect the land use change.The factors are determined by analyzing accessibility (road density, distance towards road, distance towards river) and land suitability (slope). In addition, multi-temporal remote sensing images were used, including Landsat 5 TM of 2002, Landsat ETM+ of 2009, ALOS AVNIR-2 of 2009, and Landsat 8 OLI of 2013.This study uses multispetral classification by applying maximum likelihood method. Multispectral classification produces land cover map for 2002, 2009, and 2013 that was subsequently analyzed and integrated with change variables as inputs in non-linear regression in Multi Layer Perceptron. Then, the probability of change are defined by using Markov Chain method. The result shows that 2,766.78 ha farm land was altered into residential area in period of 2002 - 2009. The biggest change was occurred in BanguntapanSubdistrict with 717.97 ha (25.21\%). Meanwhile, 804.69 ha of mixed plantation and forest were converted in residential land, with the largest change area located in ImogiriSubdistrict (361.02 ha 6.63\%). In addition, the spatial model using the combined MLP and MC generates best prediction accuracy of $86.16 \%$ and kappa value of 0.79 (substantial agreement). Therefore, the model can be applied to estimate the land use in 2016.

Key words: markov chain; multi-layer perceptron; land use change; prediction.

\section{PENDAHULUAN}

Kota Yogyakarta dengan wilayah administrasi yang relatif kecil memiliki perkembangan jumlah penduduk yang besar, sehingga menimbulkan perkembangan fisik kota yang ditandai dengan perkembangan permukiman mengarah ke daerah pinggiran kota(Kabupaten Bantul). Perubahan penggunaan lahan ini perlu dipantau agar terjadinya perubahan penggunaan lahan dapat dikendalikan sehingga tidak menimbulkan masalah sosial ekonomi dan lingkungan. Gambaran 
penggunaan lahan di masa yang akan datang melalui pemodelan spasial diperlukan sebagai masukan dalam pengambilan keputusan pemerintah dalam menentukan kebijakan-kebijakannya.

Dalam rangka pemantauan perubahan penggunaan lahan, diperlukan informasi penggunaan lahan dari waktu ke waktu. Kajian perubahan penggunaan lahan secara tidak langsung dapat dilakukan melalui suatu model. Model adalah representasi kenyataan yang disederhanakan (Thomas and Hugget, 1980). Model merupakan pendekatan yang mampu mengungkap dinamika sistem penggunaan lahan (Verburg, 2006 dalam Pimenta, et al., 2008). Pendekatan dalam merancang pemodelan perubahan penggunaan lahan terdiri atas top-down approach dan bottom-up approach (Pimenta, et al., 2008). Pendekatan top-down didasarkan pada kondisi daerah penelitian dengan pendekatan matematis atau statistik sedangkan pendekatan bottom-up didasarkan pada pelaku sebagai pengendali perubahan. Pendekatan top-down dapat memanfaatkan data sensus maupun data penginderaan jauh (Pimenta, etal., 2008).Menurut Baysal (2013) penelitian terkait pemodelan perubahan penggunaan lahan dapat dikelompokkan ke dalam 2 (dua) kategori yaitu berbasis agent dan berbasis pola. Pemodelan berbasis agent terkait dengan pelaku/actor yang melakukan simulasi perubahan sedangkan berbasis pola terkait penggunaan lahan saat ini dan perubahannya dari waktu ke waktu. Pemodelan berbasis pola salah satunya adalah dengan metode Markov Chain (MC).Markov Chain (MC) adalah suatu proses stokastik yang memiliki sifat bahwa suatu fenomena di masa yang akan datang tidak dipengaruhi oleh fenomena di masa lalu melainkan hanya dipengaruhi oleh fenomena saat ini saja. Prinsip dasar MC adalah mengukur probabilitas pada serangkaian kejadian di masa sekarang untuk memprediksi kejadian di masa depan. Hal ini menunjukkan sifat kebergantungan dalam MC, sehingga dapat dimanfaatkan untuk penyusunan model simulasi termasuk perubahan penggunaan lahan.

Berbagai penelitian untuk kajian perubahan penggunaan lahan menggunakan kombinasi metode untuk meningkatkan ketelitian pemodelan. $\underline{\mathrm{Ye} \text { and } \mathrm{Bai}}$ (2008), Xin, et al. (2012), Paramita (2010), Al-sharif (2013), Uktoro (2013) melakukan penelitian perubahan penggunaan lahan dengan mengkombinasikan Cellular Automata (CA) dengan MC dan Wijaya dan Susilo (2013) menggunakan metode Cellular Automata dengan regresi logistik untuk monitoring perkembangan lahan terbangun. Almeida (2003), Omrani, et al. (2012), Moghaddam, et al. (2009), Xu, et al., (2008), Yeh, et al. (2002) melakukan pemodelan perubahan penggunaan lahan dengan mengkombinasikan Cellular Automata dengan Artificial Neural Network (ANN).

CA adalah suatu metode komputasi untuk memprediksi perubahan sistem dinamik yang bergantung pada aturan sederhana dan berkembang hanya menurut aturan tersebut dari waktu ke waktu. CA melakukan proses komputasi berdasar prinsip ketetanggaan sel (neighbourhood).CA lebih realistik untuk menemukan rumus transisi yang merepresentasikan tenaga dorongan dan tarikan pada perubahan (Lahti, 2008 dalam Uktoro 2013). Kelemahan CA adalah lebih menunjukkan proses pertumbuhan dan prediksi tumbuhnya suatu piksel namun tidak memberikan informasi penyebab tumbuhnya yaitu hubungan kekerabatan antar variabel terikat (dependent variable) dan variabel bebasnya (independent variable). Oleh karena itu metode ini sering dikombinasikan dengan metode lain guna mengatasi kelemahan untuk meningkatkan ketelitiannya.

Seiring dengan perkembangan ilmu komputasi, metode Artificial Neural Network (ANN) semakin banyak digunakan untuk berbagai aplikasi. Metode Artificial Neural Network (ANN) atau jaringan syaraf tiruan merupakan metode learning machine (pembelajaran mesin) yang dapat mengenali pola dari masukan atau contoh yang diberikan dan juga termasuk ke dalam supervised learning. Multi-layer Perceptron (MLP) adalah salah satu bentuk arsitektur jaringan ANN yang paling banyak digunakan. MLP dapat diterapkan dalam analisis diskriminan non linier (untuk klasifikasi) dan sebagai fungsi regresi non linear (Chang, 2012). Meskipun demikian belum banyak penelitian yang memanfaatkan MLP sebagai fungsi regresi, padahal MLP sebagai fungsi regresi mampu mendeteksi secara implisit hubungan nonlinier yang kompleks antara variabel dependen dan independen serta memiliki kemampuan untuk mendeteksi semua interaksi yang mungkin terjadi diantara variabel prediktor (Tu, 1996). MLP memiliki keuntungan menggambarkan hubungan yang ada antara variabel input dan output tanpa diketahui sebelumnya hubungan antara variabel-variabel itu sendiri.

Penelitian ini bertujuan mengkajikemampuan citra satelit penginderaan jauh resolusi menengah Landsat untuk ekstraksi informasi penggunaan lahan tahun 2002, 2009 dan 2013 dan mengkaji perubahan penggunaan lahan secara spasial di sebagian Kabupaten Bantul dari tahun 2002 sampai dengan tahun 2009 dan menyusun pemodelan perubahan penggunaan lahan dengan metode Multi Layer Perceptron dan Markov Chain di sebagian Kabupaten Bantul pada tahun 2013 
dengan mempertimbangkan faktor-faktor yang mempengaruhi perubahan penggunaan lahan. Faktorfaktor yang mempengaruhi perubahan penggunaan lahan ditentukan secara a-priori berdasar kondisi di lapangan dan studi literatur meliputi aksesbilitas (kepadatan jalan, jarak terhadap jalan, jarak terhadap sungai) dan kesesuaian lahan (kemiringan lereng).

\section{METODE PENELITIAN}

Bahan yang digunakan dalam penelitian ini adalah citra satelit Landsat path 120 row 65 dengan 3 (tiga) waktu perekaman bersumber dari United States Geological Survey (USGS),yaitu:citra satelit Landsat 7 ETM+ tahun 2002 tanggal perekaman 21 Agustus 2002,citra satelit Landsat 5 TM tahun 2009 tanggal perekaman 31 Juli 2009 dan citra satelit Landsat 8 OLI tahun 2013 dengan tanggal perekaman 24 juni 2013.Citra Google Earth dengan tanggal perekaman 7 November 2003, Citra ALOS AVNIR-2 perekaman 20 Juni 2009, Peta Rupa Bumi Indonesia skala 1 : 25.000 nomor lembar 1408-221, 1408-222, 1408-223, 1408224 dan 1408-313, Peta Geologi Lembar Yogyakarta 1408-2 dan Lembar Surakarta 1408-3 skala1 : 100.000 dan Norma Standard Prosedur Pemetaan Tematik Badan Pertanahan Nasionaal (BPN) tahun 2012.

Penelitian dilakukan dengan melakukan klasifikasi multispektral terhadap citra satelit Landsat 7 ETM+ 2002, Landsat 5 TM 2009 dan Landsat 8 OLI 2013. Hasil klasifikasi spektral menghasilkan peta penutup lahan yang selanjutnya dengan pendekatan karakteristik medan diturunkan menjadi peta penggunaan lahan. Penggunaan lahan tahun 2002 dan 2009 dibandingkan dengan menggunakan cross tabulation (tabulasi silang) untuk menghasilkan matriks transisi. Hasil perbandingan dengan melibatkan faktor yang mempengaruhi perubahan (variabel perubahan) digunakan sebagai input dalam pemodelan dengan metode Multi Layer Perceptron. Variabel perubahan penggunaan lahan ditentukan secara a-priori berdasar kondisi di lapangan dan studi literatur meliputi aksesbilitas (kepadatan jalan, jarak terhadap jalan, jarak terhadap sungai) dan kesesuaian lahan (kemiringan lereng). Perhitungan probabilitas besar area perubahan menggunakan Markov Chain.

\section{HASIL DAN PEMBAHASAN}

Penelitian ini berlokasi di sebagian wilayah Kabupaten Bantul. Kabupaten Bantul terletak antara

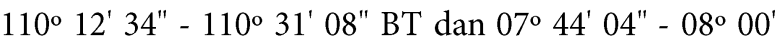
$27^{\prime \prime}$ LS. Di sebelah timur berbatasan dengan Kabupaten Gunungkidul, di sebelah utara berbatasan dengan Kota Yogyakarta dan Kabupaten Sleman, di sebelah barat berbatasan dengan Kabupaten Kulon Progo, dan di sebelah selatan berbatasan dengan Samudra Indonesia. Wilayah Penelitian meliputi sebagian dari Kabupaten Bantul yaitu mencakup Kecamatan Bantul, Jetis, Imogiri, Pleret, Piyungan, Banguntapan, Sewon dan Kasihan sebagaimana 0 .

Tahap pra pemrosesan citra bertujuan agar citra dapat digunakan dan menghasilkan data yang baik dan benar. Tahap ini terdiri dari koreksi radiometrik dan koreksi geometrik. Koreksi radiometrik ditujukan untuk memperbaiki nilai piksel supaya sesuai dengan nilai pancar obyek yang sebenarnya.Berdasar pada asumsi bahwa nilai terendah suatu piksel dalam suatu liputan seharusnya bernilai nol maka selisih nilai terendah pada suatu citra terhadap nilai nol dianggap sebagai nilai gangguan atmosfer.
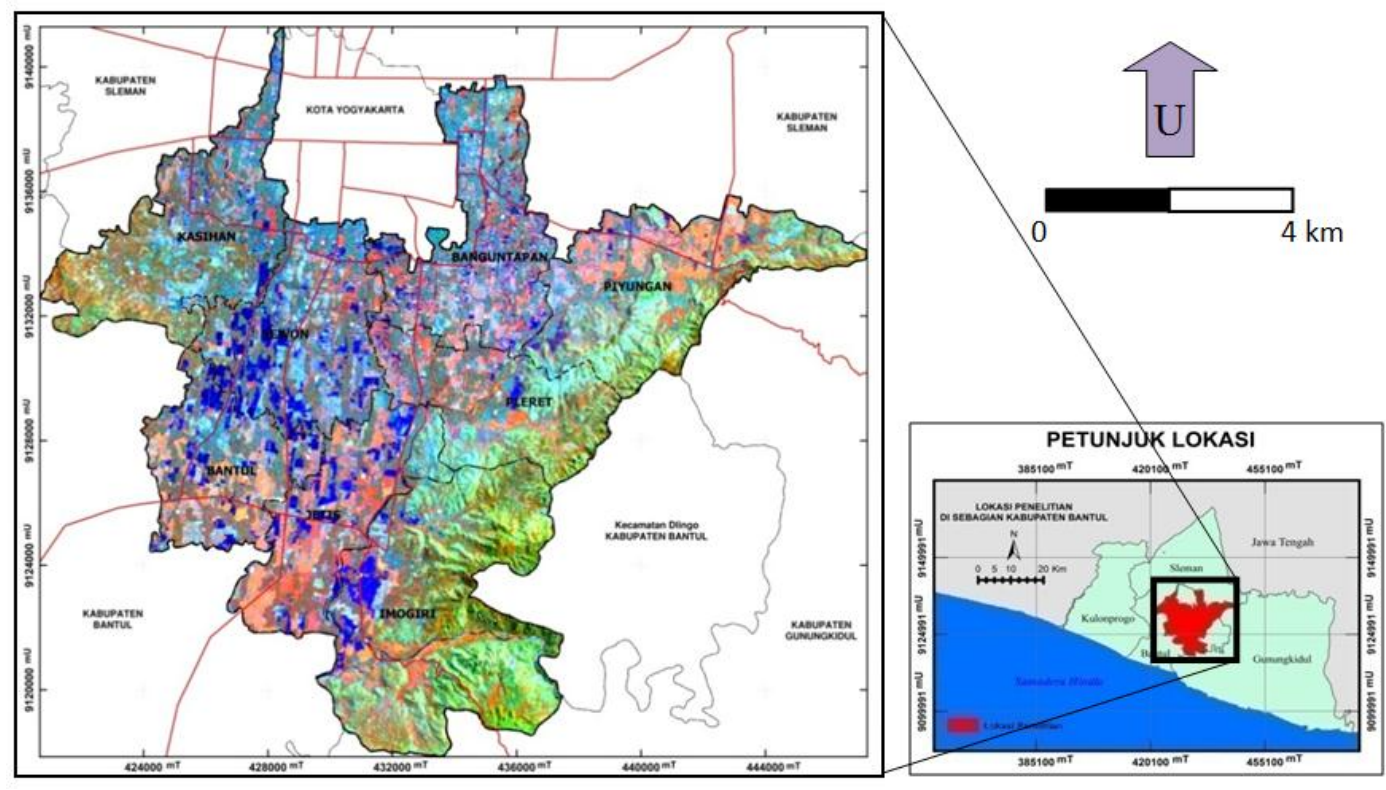

http://jurnal.ugm.ac.id/mgi | 11 
Gambar 1. Lokasi Penelitian yang Tersaji pada Citra Landsat 7 ETM+ Tahun 2002 Komposit RGB 451

Hasil identifikasi pada masing-masing saluran pada masing-masing citra menunjukkan bahwa nilai terendah memiliki nilai nol. Oleh karena itu tidak perlu lagi dilakukan koreksi radiometrik lagi mengingat asumsi sebagaimana tersebut di atas sudah terpenuhi. Koreksi geometrik adalah koreksi untuk mengatasi kesalahan geometri citra yang disebabkan oleh posisi, orbit maupun sikap sensor pada saat satelit mengindera bumi, serta pengaruh kelengkungan dan putaran bumi.

Sebelum dilakukan koreksi geometrik dilakukan pemotongan citra dengan area persegi yang melingkupi seluruh wilayah penelitian. Hal ini dimaksudkan agar proses koreksi geometri tidak serumit jika pemotongan citra berdasar pada batas administrasi. Oleh karena itu pemotongan citra berdasar batas administrasi dilakukan setelah dilakukan koreksi geometrik mengingat batas administrasi wilayah kajian cukup rumit. Koreksi geometrik bertujuan untuk mengembalikan posisi piksel sedemikian rupa pada posisi yang seharusnya sehingga sama dengan posisi pada kenampakan objek di permukaan bumi.Dalam penelitian ini digunakan 20 (dua puluh) titik ikat dengan menggunakan peta (image to map) yaitu Peta Rupa Bumi Indonesia (RBI) skala $1: 25.000$ yang meliputi lembar 1408-221, 1408-222, 1408-223, 1408224, 1408-311 dan 1408-313. Metode interpolasi nilai piksel yang digunakan yakni nearest neighbour. Hasil koreksi geometrik terhadap citra Landsat 7 ETM+ tahun 2002 menghasilkan RMS Error sebesar 0,184017 dan terhadap Landsat 5 TM 2009 menghasilkan RMS Error sebesar 0,132978. Koreksi geometrik juga dilakukan terhadap citra Alos AVNIR-2 2009 yang akan digunakan sebagai uji akurasi terhadap hasil klasifikasi multispektral Landsat 5 TM 2009. Koreksi geometrik terhadap citra ALOS AVNIR-2 2009 menghasilkan RMS Error sebesar 0,252188. Demikian halnya juga terhadap Landsat 8 OLI 2013 sebesar 0,257775 .

Dalam klasifikasi penutup lahan terlebih dahulu ditentukan skema klasifikasi untuk memilih kategori kelas yang akan diambil untuk keperluan klasifikasi. Dalam penelitian ini klasifikasi penggunaan lahan mengacu pada standard Badan Pertanahan Nasional (BPN) tahun 2012 dengan tingkat klasifikasi untuk pemetaan skala 1:100.000 dengan modifikasi (0).Klasifikasi penutup lahan dilakukan dengan melakukan klasifikasi multispektral dengan metode maximum likelihood (klasifikasi supervised). Oleh karena itu setelah penentuan skema klasifikasi penutup lahan, proses selanjutnya adalah penentuan sampel atau sering disebut ROI (Region Of Interest). Penentuan sampel berdasar respon spektral masing-masing objek pada citra oleh karena itu kelas penutup lahan dirinci lagi ke dalam kelas-kelas spektral terlebih dahulu. Evaluasi tingkat keterpisahan antar kelas terhadap sampel yang telah diambil selanjutnya dilakukan. Nilai indeks keterpisahan terkecil pada Landsat 7 ETM+ 2002 terjadi pada kelas Tubuh air1 dan Tubuh air2 yaitu 1.40252854. Sedangkan pada Landsat 5 TM 2009 terjadi antara tanah terbuka kering dan tanah terbuka agak kering sebesar 1.42265240. Nilai indeks keterpisahan terkecil pada Landsat 8 OLI 2013 terjadi pada kelas Tanah terbuka basah dan Tanah terbuka agak basah yaitu sebesar 1.11794589. Hal ini masih diterima karena kedua kelas tersebut nantinya akan dimerging menjadi satu kelas penutup lahan yaitu kelas lahan terbuka.

Berdasar nilai indeks keterpisahan yang memenuhi persyaratan selanjutnya dilakukan klasifikasi multispektral yang menghasilkan klasifikasi kelas spektral. Kelas spektral selanjutnya digabungkan (class merging) menghasilkan klasifikasi kelas penutup lahan. Uji akurasi pada penutup lahan tentatif 2002 dilakukan dengan citra Google Earth perekaman 7 November 2003 dan pada penutup lahan tentatif 2009 dilakukan dengan citra Alos AVNIR-2 perekaman 20 Juni 2009. Hasil uji akurasi menggunakan confusion matrixdiperoleh hasil uji akurasi kelas penutup lahan tahun 2002 sebesar 93.6615\% dan Kappa Coefficient $=$ 0.9095 dan untuk kelas penutup lahan tahun 2009 sebesar $94.7401 \%$ dan Kappa Coefficient $=0.9231$. Uji akurasi pada penutup lahan tentatif 2013 dilakukan survei lapangan.Hasil uji akurasi menggunakan confusion matrixdiperoleh hasil uji akurasi kelas penutup lahan tahun 2013 sebesar $95.5582 \%$ dengan koefien Kappa 0.9253.

Dalam rangka ekstraksi informasi penggunaan lahan dari penutup lahan digunakan pendekatan landscape-ecological approach yaitu ekstraksi dengan pendekatan karakteristik medan.Pendekatan karakteristik medan menggunakan pendekatan klasifikasi bentuk lahan. Satuan bentuk lahan hasil interpretasi citra dengan bantuan Peta Geologi yang terdapat dalam wilayah penelitian antara lain dataran aluvial, dataran banjir, gawir-sesar, perbukitan terisolir dan perbukitan terkikis (Tabel 2).

Penggunaan lahan hasil integrasi antara penutup lahan dan satuan bentuk lahan sebagaimana Gambar 2, 3, dan 4. Hasil uji akurasi menggunakan confusion matrixdiperoleh hasil uji akurasi penggunaan lahan tahun 2002 sebesar 93.4095\% dengan koefisien Kappa 0.9052dan untuk penggunaan lahan tahun 2009 sebesar 94.4272\% dengan koefisien Kappa 0.9128. Pada 
penggunaan lahan tahun 2013 dihasilkan uji akurasi

sebesar 95.5582\% dengan koefien Kappa 0.9227.

Tabel 1. Skema Klasifikasi Penutup Lahan dan Skema Klasifikasi Penggunaan Lahan

\begin{tabular}{cc}
\hline Klasifikasi Penutup Lahan Skala 1:100.000 & Klasifikasi Penggunaan Lahan Skala 1:100.000 \\
\hline Lahan terbangun & Permukiman \\
Lahan terbuka & Lahan Pertanian \\
Tubuh air & Danau/Tambak/Sungai \\
Vegetasi & Hutan dan kebun campuran \\
\hline
\end{tabular}

Sumber : NSPK BPN RI (2012) dengan Modifikasi

Tabel 2. Skema Hubungan Klasifikasi Penutup Lahan dan Satuan Bentuk Lahan untuk Menghasilkan Klasifikasi Penggunaan Lahan

\begin{tabular}{lcccc}
\hline Renutup Lahan & & & \\
Satuan & Lahan Terbangun & Lahan Terbuka & Tubuh Air & Vegetasi \\
Bentuklahan & & & & Lahan pertanian \\
Dataran Aluvial & Permukiman & Lahan pertanian & Lahan pertanian & Danau/Tambak/Sungai \\
Dataran Banjir & Danau/Tambak/Sungai & Danau/Tambak/Sungai & Danau/Tambak/Sungai & Hutan dan Kebun \\
Gawir-Sesar & Permukiman & Hutan dan Kebun & Hutan dan Kebun & Campuran \\
$\begin{array}{l}\text { Perbukitan } \\
\text { Terisolir }\end{array}$ & Permukiman & Campuran & Campuran & Hutan dan Kebun \\
$\begin{array}{l}\text { Perbukitan } \\
\text { Terkikis }\end{array}$ & Permukiman & Campuran & Hutan dan Kebun & Campuran \\
\hline
\end{tabular}

Sumber : Pengolahan Data (2014)
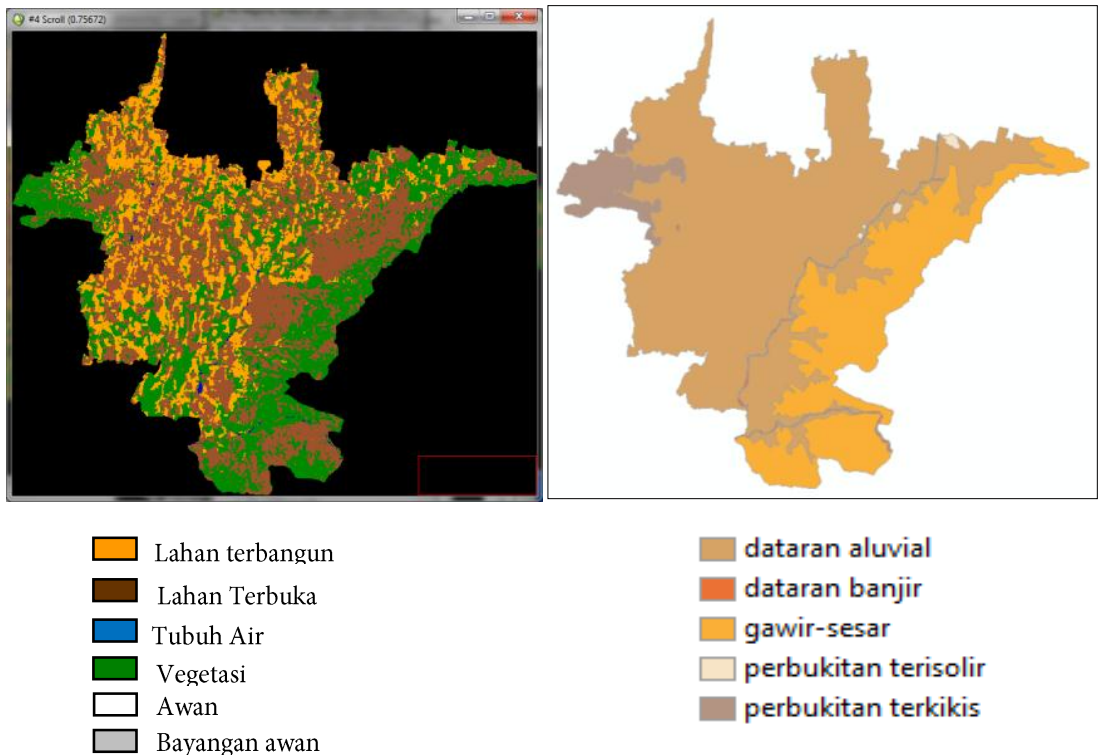

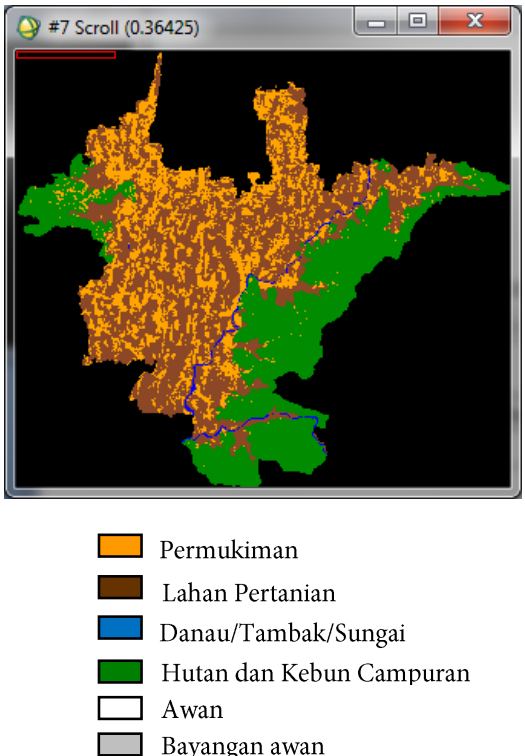

Gambar 2. Hasil Klasifikasi Penggunaan Lahan 2002 (kanan), Satuan Bentuklahan (tengah), dan Integrasi Penutup Lahan 2002 (kiri) 

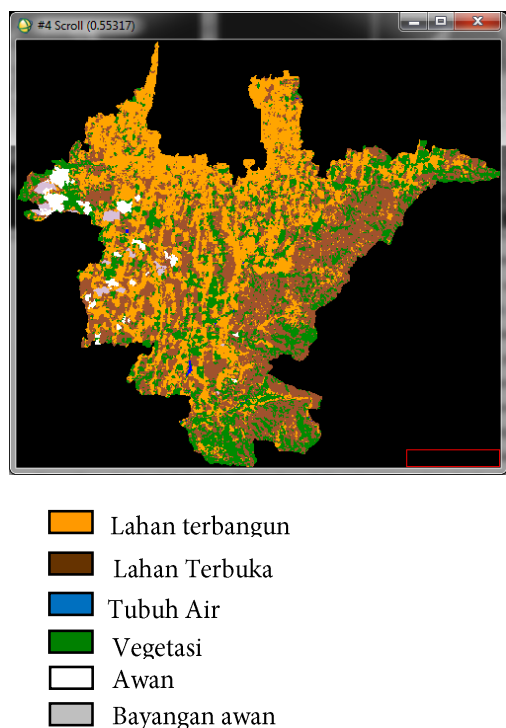

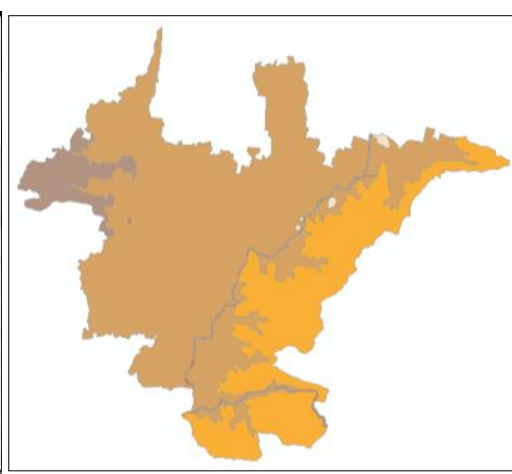

dataran aluvial

dataran banjir

$\square$ gawir-sesar

$\square$ perbukitan terisolir

perbukitan terkikis
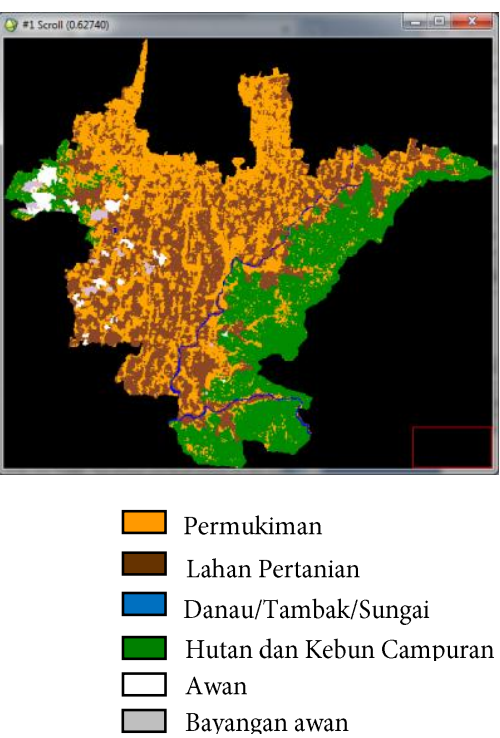

Gambar 3. Hasil Klasifikasi Penggunaan Lahan 2009 (kanan), Satuan Bentuklahan (tengah), dan Integrasi Penutup Lahan 2009 (kiri)
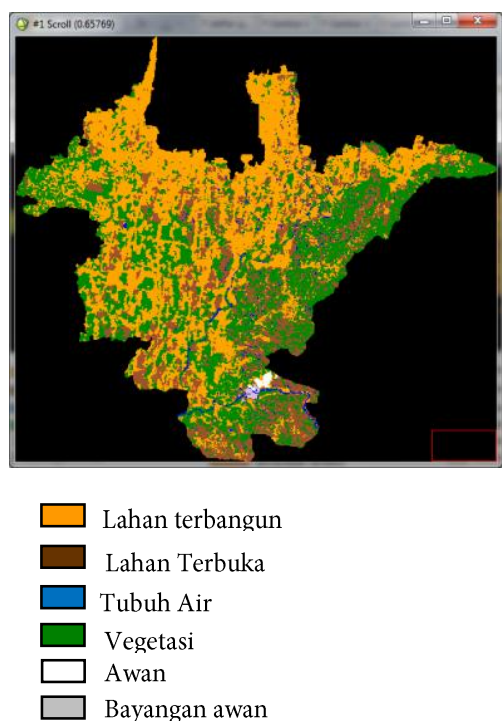
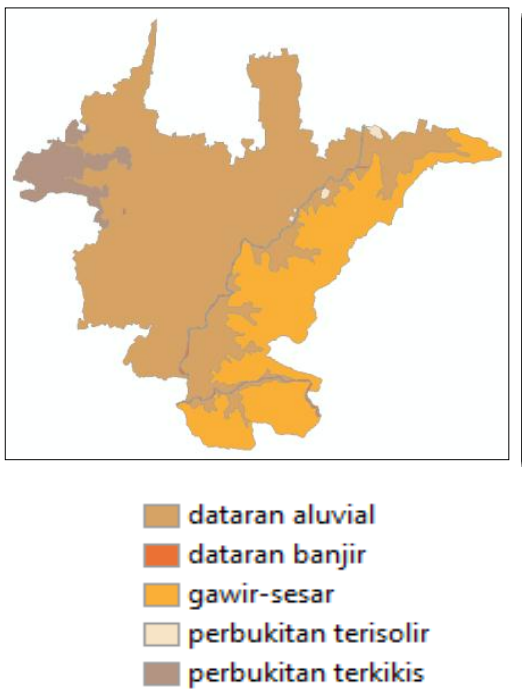
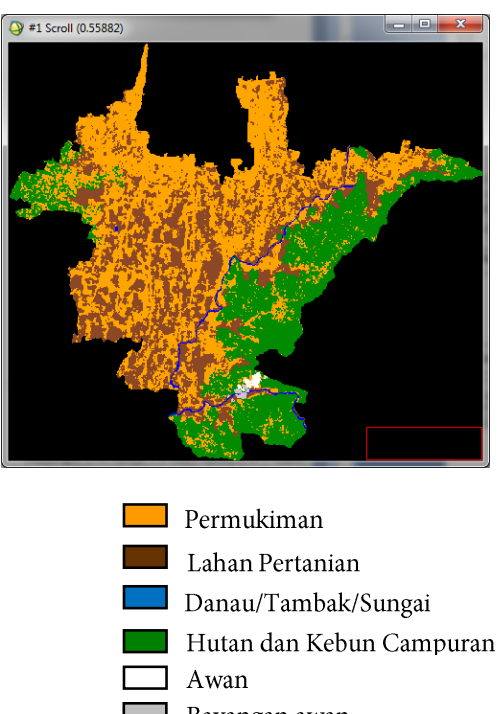

Gambar 4. Hasil Klasifikasi Penggunaan Lahan 2013 (kanan), Satuan Bentuklahan (tengah), dan Integrasi Penutup Lahan 2013 (kiri)

Hasil crosstabulation penggunaan lahan 2002-2009 sebagaimana 0 menunjukkan total perubahan bersih (net change) antara tahun 2002 dan 2009 untuk penggunaan lahan pemukiman bertambah sebesar $3.211,47$ ha dan lahan pertanian berkurang sebesar $2.432,52$ ha serta hutan dan kebun campuran seluas 778,95 ha. Sebaran perubahan penggunaan lahan sebagaimana 0 . Terjadinya perubahan penggunaan lahan dari permukiman ke penggunaan lainnya adalah dikarenakan pada tahun 2006 wilayah penelitian mengalami gempa yang cukup besar sehingga banyak permukiman yang rusak.

Tahap pemodelan perubahan penggunaan lahan terdiri atas Tahap Potensial Transisi (Transition Potentials) yaitu tahap untuk menentukan lokasi yang berpotensi untuk mengalami perubahan, Tahap Area Transisi yaitu tahap untuk menentukan besar luasan yang mengalami perubahan, Tahap Prediksi Perubahan Penggunaan Lahan (Change Prediction) yaitu tahap menentukan hasil prediksi berdasar pada hasil dari dua tahap sebelumnya tersebut dan Tahap Validasi yaitu tahap uji akurasi hasil prediksi. 
Tabel 3. Matriks Perubahan Luas Penggunaan Lahan (PL) Antara Tahun 2002 dan 2009 dalam Satuan Hektar

\begin{tabular}{|c|c|c|c|c|c|c|}
\hline $\mathrm{PL} 2002 \quad$ PL 2009 & Permukiman & $\begin{array}{c}\text { Lahan } \\
\text { Pertanian }\end{array}$ & $\begin{array}{l}\text { Hutan Dan Kebun } \\
\text { Campuran }\end{array}$ & $\begin{array}{l}\text { Danau/Tambak/ } \\
\text { Sungai }\end{array}$ & Total T1 & Losses \\
\hline Permukiman & $5.391,63$ & 334,26 & 25,74 & 0 & $5.751,63$ & 360 \\
\hline Lahan Pertanian & $2.766,78$ & $7.546,50$ & 0 & 0 & $10.313,28$ & $2.766,78$ \\
\hline Hutan dan Kebun & 804,69 & 0 & $6.348,06$ & 0 & $7.152,75$ & 804,69 \\
\hline \multicolumn{7}{|l|}{ Campuran } \\
\hline Danau/Tambak/ & 0 & 0 & 0 & 199,26 & 199,26 & 0 \\
\hline \multicolumn{7}{|l|}{ Sungai } \\
\hline Total T2 & $8.963,10$ & $7.880,76$ & $6.373,80$ & 199,26 & $19.485,45$ & \\
\hline Gain & $3.571,47$ & 334,26 & 25,74 & 0 & & \\
\hline Net Change & $3.211,47$ & $-2.432,52$ & $-778,95$ & 0 & & \\
\hline
\end{tabular}

Sumber : Pengolahan Data (2014)

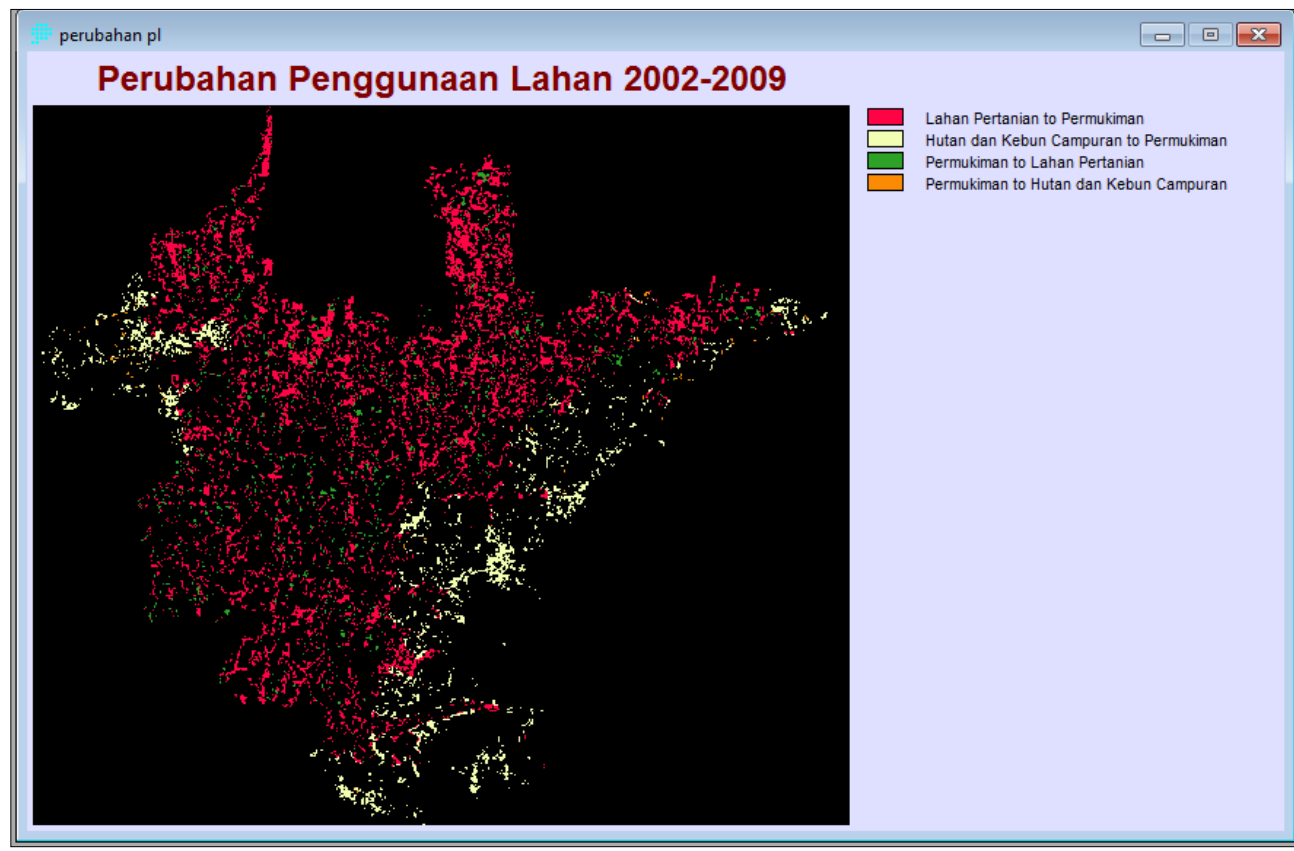

Gambar 5. Perubahan Penggunaan Lahan Dari Tahun 2002 Ke Tahun 2009

Tahap potensial transisi untuk menentukan lokasi yang berpotensi mengalami perubahan menggunakan metode MLP. Input yang digunakan antara lain variabel perubahan berupa kepadatan jaringan jalan, jarak terhadap jalan, kemiringan lereng, jarak terhadap sungai dan peta penggunaan lahan tahun 2002 (evidence likelihood). Untuk proses pelatihan digunakan peta perubahan penggunaan lahan 20022009. Ilustrasi proses penentuan potensial transisi sebagaimana 0. Berdasar proses MLP menggunakan semua variabel perubahan dihasilkan accuracy rate MLP sebesar 73,44\%

Penentuan luasan alokasi perubahan menggunakan metode Markov Chain (MC). Alokasi luas perubahan diperoleh dengan cross tabulation Peta Penggunaan Lahan antara 2002-2009untuk menghasilkan Matriks Area Transisi/MAT tahun 2009-2013. Probabilitas dengan MarkovChain berlaku jika rentang tahun pemodelan sama dengan rentang tahun inputnya. Mengingat data penggunaan lahan tidak dapat memenuhi kondisi tersebut maka dilakukan modifikasi matriks menggunakan persamaan yang dikembangkan (Takada, etal., 2010). Hasil MAT modifikasi sebagaimana ditunjukkan pada0.

Setelah diperoleh lokasi atau posisi piksel yang memiliki probabilitas yaitu berupa Peta Potensial Transisi (PPT) dan luas perubahan berupa Matriks Area Transisi (MAT) dilakukan proses alokasi. Alokasi ini menggunakan prosedur alokasi lahan secara kompetitif dengan algoritma seperti MOLA (Multi Objective Land Allocation). Hasil alokasi ini berupa Peta Prediksi Penggunaan lahan 2013 (Gambar 8). Untuk validasi hasil prediksi maka peta hasil prediksi ditumpangsusunkan dengan Peta Penggunaan Lahan tahun 2013 hasil klasifikasi citra Landsat 8 OLI tahun 2013. Berdasarkan perhitungan confusion matrixdiperoleh Overall Accuracy sebesar 86,16\% dengan Kappa sebesar 0,79 (substantial agreement). 


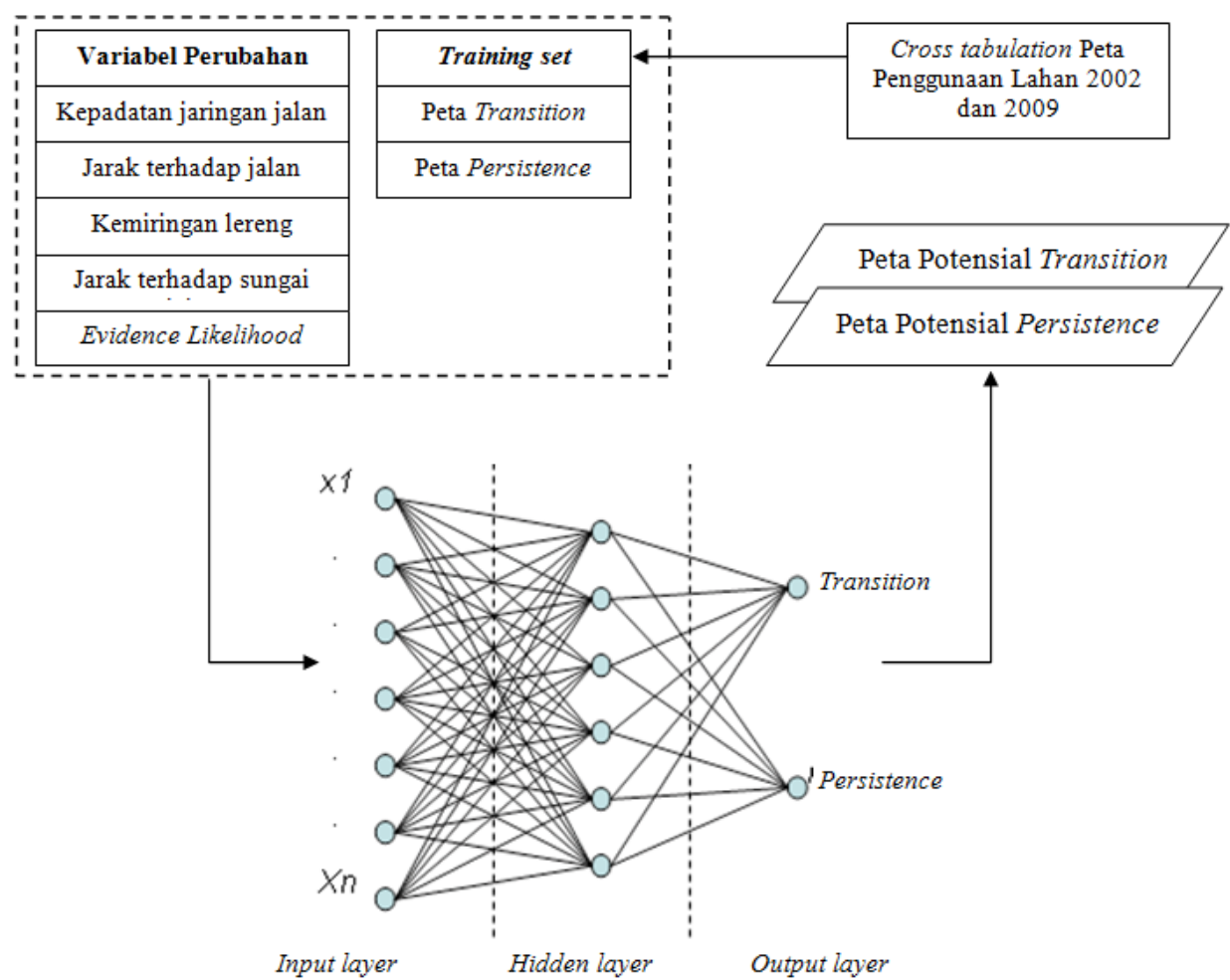

Gambar 6. Penentuan Potensial Transisidengan MLP Tahun 2002-2009

\begin{tabular}{|l|l|l|l|l|l|}
\hline \multicolumn{1}{|l|}{ Transition Probabilities Grid } & \\
\hline \multicolumn{3}{|c|}{ Probability of changing to: } \\
\hline & Permukiman & Lahan Pertanian & Hutan dan Kebun Campuran & Danau/Tambak/Sungai \\
\hline Permukiman & 0.9598 & 0.0000 & 0.0000 & 0.0000 \\
\hline Lahan Pertanian & 0.1728 & 0.8272 & 0.0000 & 0.0000 \\
\hline Hutan dan Kebun Campuran & 0.0664 & 0.0000 & 0.9336 & 0.0000 \\
\hline Danau/Tambak/Sungai & 0.0000 & 0.0000 & 0.0000 & 1.0000 \\
\hline
\end{tabular}

Gambar 7. Matriks Area Transisi Tahun 2009-2013
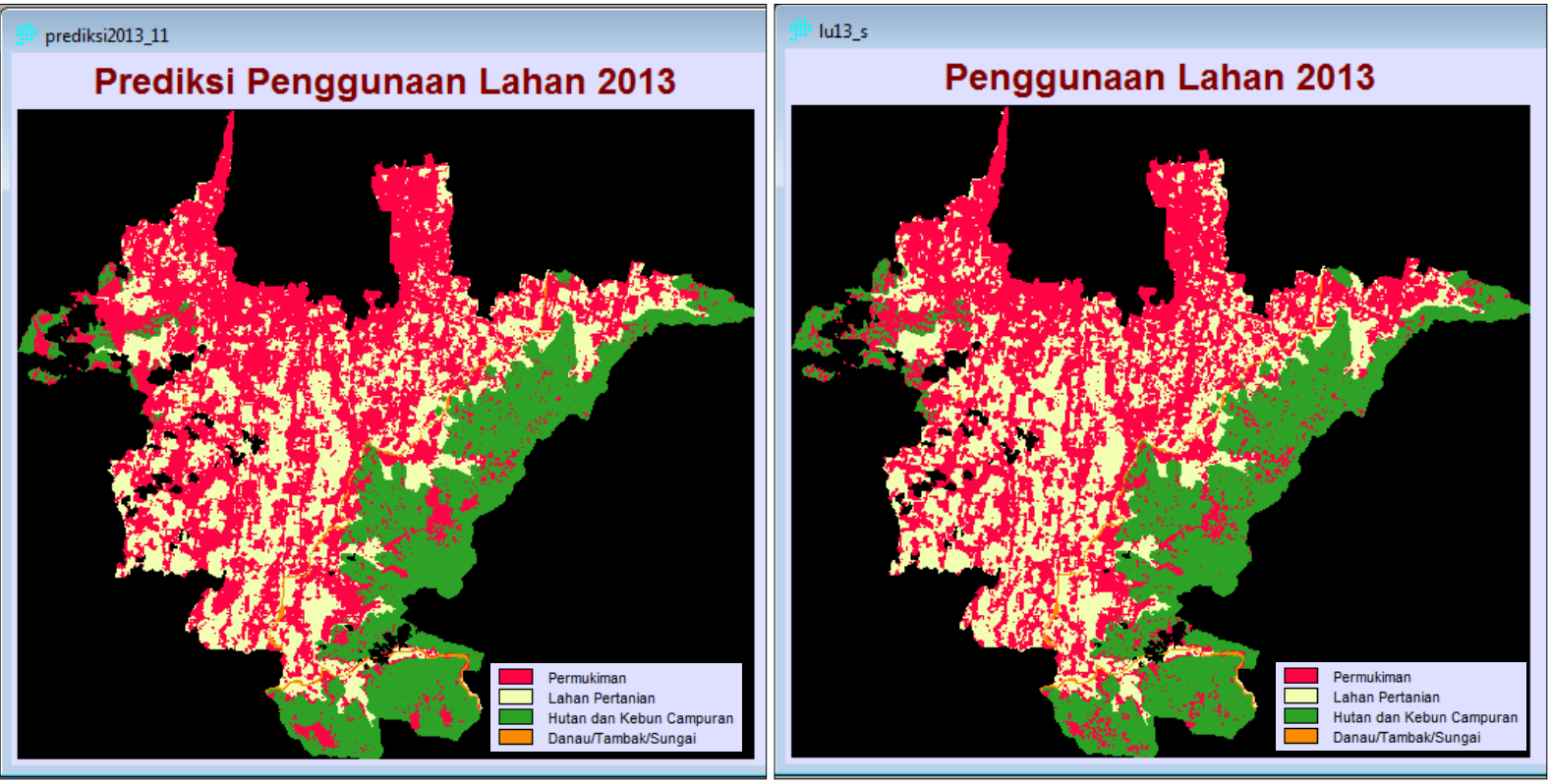

Gambar 8. Hasil Prediksi Penggunaan Lahan Tahun 2013 (kiri) dan Penggunaan Lahan Tahun 2013 (kanan) 


\section{KESIMPULAN}

1. Hasil klasifikasi tersedia citra satelit penginderaan jauh resolusi menengah Landsat menggunakan metode maksimum likelihood memiliki akurasi klasifikasi penggunaan lahan pada tahun 2002 sebesar 93,4095\%, pada tahun 2009 sebesar 94,4272\% dan pada tahun 2013 sebesar 95,5582\%.

2. Penggunaan lahan di sebagian Kabupaten Bantul antara tahun 2002-2009 mengalami perubahan dari lahan pertanian menjadi permukiman seluas 2.766,78ha dengan perubahan terluas terjadi di Kecamatan Banguntapan seluas 717,97 ha (25,21\%). Perubahan kelas penggunaan lahan hutan dan kebun campuran ke permukiman seluas 804,69ha dimana perubahan terluas terjadi di Kecamatan Imogiri seluas 361,02 ha $(6,63 \%)$. Sehingga pada periode tahun 2002-2009 terjadi penambahan permukiman seluas $3.571,47$ ha. Pertumbuhan permukiman di sebagian Kabupaten Bantul periode 2002-2009 kaitannya dengan variabel perubahan penggunaan lahan menunjukkan pola dimana variabel perubahan berupa kepadatan jaringan jalan, jarak terhadap jalan dan kemiringan lereng lebih berpengaruh terhadap terjadinya pertumbuhan permukiman dibandingkan variabel jarak terhadap sungai.

3. Pada pemodelan perubahan penggunaan lahan 2013 dengan menggunakan kombinasi MLP dan MC dihasilkan akurasi hasil prediksi terbaik dengan overall accuracy 86,16 \% dan Kappa sebesar 0,79 (substantial agreement), sehingga model dapat diaplikasikan untuk prediksi penggunaan lahan pada tahun-tahunyang akan datang.

\section{DAFTAR PUSTAKA}

Almeida, C. M., (2003). Spatial Dynamic Modelling as a Planning Tool: Simulation of Urban Land Use Change in Bauru and Piracicaba (SP), Brazil. Sao Jose dos Campos. 321p. Published PhD Thesis. Brazilian National Institute for Space Research (INPE-10567-TDI/942/B).

Al-sharif, A. dan Pradhan, B. (2013). Monitoring and predicting land use change in Tripoli Metropolitan City using an integrated Markov chain and cellular automata models in GIS. Paper. Saudi Society for Geosciences. Springer.

Baysal (2013). Urban Land Use And Land Cover Change Analysis And Modeling A Case Study Area Malatya, Turkey. Thesis. Master Program in Geospatial Technology. Germany, Universität Münster; Spain, Universitat Jaume I; and Portugal, Universidade Nova de Lisboa.
Chang, H. (2012). Multilayer Perceptron. Institute of Computing Technology, Chinese Academy of Sciences. Access from http://www.jdl.ac.cn/user/hchang/course_staffs/10_ multilayer\%20perceptron.pdf.

Moghaddam, H.K. and Samadzadegan, F., (2009). Urban Simulation Using Neural Networks and Cellular Automata for Land Use Planning. Proceeding.Iran : REAL CORP 2009 Tagungsband.

Omrani, H., Charif, O., Gerber, P., Bodis, K., Basse, R.M. (2012). Simulation of land use changes using cellular automata and artificial neural network. CEPS/INSTEAD Working Papers.

Paramita, B. (2010). Model Cellular Automata untuk kajian perkembangan wilayah menggunakan data penginderaan Jauh (studi kasus : Kawasan Perkotaan Kedungsepur). Tesis. Yogyakarta: Fakultas Geografi, Universitas Gadjah Mada.

Pimenta, P., Coelho, A., Costa, S., Moreira, E., Aguiar, A.P., Camara, G., Araujo, R., Riberio, A. (2008). Land change modeling and institutional factors: heterogeneous rules of territory use in the Brazilian Amazonia. Paper. Belém, PA : Departamento de Informática, Universidade Federal do Pará (UFPA).

Takada, T., Miyamoto, A., Hasegawa, S.F. (2010). Derivation of yearly transition probability matrix for land-use dynamics and its applications. Landscape Ecol (2010). 25:561-572. Springer.

Thomas, R. W. and Huggett, R.J. (1980).Modelling in Geography: A Mathematical Approach. Totowa, NJ: Barnes and Noble Books

Tu, J.V., (1996). Advantages and disadvantages of using artificial neural networks versus logistic regression for predicting medical outcomes. Journal of Clinical Epidemiology (1996). 49:1225-1231

Uktoro, A.I., (2013), Membangun Model Sawah Lestari Dan Model Prediksi Perubahannya Menggunakan Cellular Automata Di Kabupaten Klaten Provinsi Jawa Tengah. Tesis. Yogyakarta: Fakultas Geografi, Universitas Gadjah Mada.

Wijaya, M. dan Susilo, B., (2013). Monitoring Perkembangan Lahan Terbangun di Kota Salatiga Menggunakan Model Cellular Automata dan Regresi Logistik Biner. Prosiding Simposium Nasional Sains Geoinformasi III 2013. ISBN 978979-98521-4-4.

Xin Y., Xin-Qi, Z., Li-Na, L. (2012). A spatiotemporal model of land use change based on ant colony optimization, Markov chain and cellular automata. Ecological Modelling. 33: 11- 19.

Xu X., Zhang J., Zhou X., (2008). Modeling urban land use changes in Lanzhou based on artificial, neural 
network and cellular automata. Proceedings of SPIE. 7413, 71431A-7-1431A-10.

Ye, B. and Bai, Z., (2008), Simulating Land Use/Cover Changes on Nenjiang County Based on CA-Markov Model. In IFIP International Federation For Information Processing. 258, 321-329.
Yeh A.G.O, Li X., (2002). Urban Simulation Using Neural Networks and Cellular Automata for Land Use Planning.Papers in Symposium on Geospatial Theory, Processing \& Application. Ottawa. 